\title{
LARGE-SCALE PATTERNS OF SNOW MELT ON ARCTIC SEA ICE MAPPED FROM METEOROLOGICAL SATELLITE IMAGERY
}

\author{
by \\ G. Scharfen, R.G. Barry \\ (Co-operative Institute for Research in Environmental Sciences, University of Colorado, \\ Boulder, CO 80309, U.S.A.) \\ and \\ D.A. Robinson, G. Kukla, M.C. Serreze
}

(Lamont-Doherty Geological Observatory of Columbia University, Palisades, NY 10964, U.S.A.)

\begin{abstract}
The seasonal progression of snow melt on the Arctic pack ice is mapped from satellite shortwave imagery (0.4-1.1 micrometers) for four spring/summer seasons (1977, 1979, 1984 and 1985). This provides the first detailed information on the temporal change of the ice surface albedo in summer and of its year-to-year variability. The average surface albedo of the Arctic Basin for the years investigated falls from between 0.75 and 0.80 in early May to between 0.35 and 0.45 in late July and early August. In the central Arctic, where ice concentration remains high and ponding on the ice is limited, the July albedo ranges from 0.50 to 0.60 . Overall, melt progresses poleward from the Kara and Barents Seas and from the southern Beaufort and Chukchi Seas, with the melt fronts meeting on the American side of the Pole. There are substantial year-to-year differences in the timing, duration and extent of the melt interval. The progression of melt in May and June of the earliest melt year (1977) was about 3 weeks ahead of the latest year (1979). By late July, the central Arctic was essentially snow free in 1977 and 1979, but more than $50 \%$ snow covered in 1984. Although limited in extent, our data base suggests relationships between snow melt and Arctic surface air temperatures in spring, spring cloudiness and the extent of late summer ice.
\end{abstract}

\section{INTRODUCTION}

The timing, duration and extent of snow melt on the pack ice has long been recognized as a critical variable influencing the summer climatic regime in the Arctic Basin, with potential impacts on other parts of the Northern Hemisphere (Fletcher 1966). The snow melt has implications for the long-term mass balance and stability of the sea ice and may serve as an indicator of $\mathrm{CO}_{2}$-induced climatic change (Barry 1985).

Up to now, direct information on melt and the resultant changes in surface reflectivity (albedo) in the basin has been limited to measurements taken at drifting stations or on fast ice and to a few aircraft programs (e.g. Laktionov 1953, Untersteiner 1961; Langleben 1971; Bryazgin and Koptev 1970; Weaver and others 1976, Holt and Digby 1985). Others have used these data to estimate regionally averaged summer albedo (e.g. Larsson and Orvig 1962; Marshunova and Chernigovskiy 1966; Posey and Clapp 1964; Hummel and Reck 1979, Robock 1980; Kukla and Robinson 1980). Estimates of July surface albedo in the central Arctic range from 0.40 to 0.65 . More recently, microwave satellite data have been used to identify the earliest phase of snow melt onset (Anderson and others, 1985) and also to estimate sea ice concentration and, indirectly, Arctic surface albedo (Carsey 1985). In the latter study, the areal coverage of bare ice was deduced from the data and the proportion of melt ponds and leads was estimated from published reports. Parameterized albedos were then assigned to each surface type and weighted according to their coverage. Central Arctic albedo in mid-July 1974 was estimated to be 0.58 with values about 0.10 lower around the margins of the basin.

In the present study, we have used operational daily meteorological satellite imagery to map the changes of surface brightness and texture associated with four spring/ summer seasons in the Arctic Basin (Figure 1). Parameterized albedos have been assigned to different brightness classes by analyzing satellite data on an image processor.

\section{DATA AND METHODS}

Imagery from the Defense Meteorological Satellite Program (DMSP) near-polar orbiter served as the primary data source for assessing surface conditions. Shortwave (0.41.1 micrometers) images with resolutions of $0.6 \mathrm{~km}$ for direct read-out products and $2.7 \mathrm{~km}$ for orbital swath

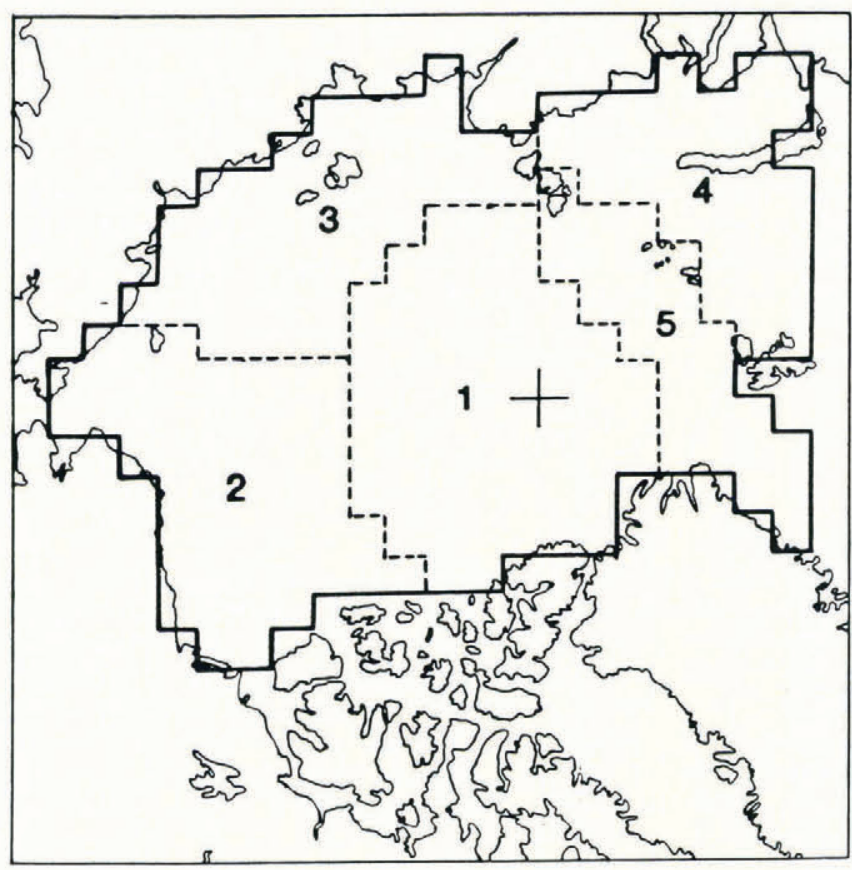

Fig.1. Arctic Basin study zone (heavy line) divided into five regions (dashed lines): 1) Central Arctic, 2) Beaufort/Chukchi Seas, 3) East Siberian/Laptev Seas, 4) Kara/Barents Seas and 5) Northwest North Atlantic. 
format images were used. Supplemental data included NOAA Very High Resolution Radiometer (VHRR) and Advanced VHRR $1.1 \mathrm{~km}$ resolution imagery.

Snow melt on the ice is recognized in the shortwave images by a characteristic decrease in brightness and a change in surface texture. As the snow dissipates, melt ponds form and bare ice is exposed (Barry 1983) (Figure 2). Landfast ice and first-year pack ice brighten somewhat when melt ponds drain (Zubov 1945; Lapp 1982; Holt and Digby 1985). Comparisons of DMSP imagery with synchronous $80 \mathrm{~m}$ resolution Landsat imagery confirm the recognition of surface features in the lower resolution products. The comparisons also show that, in most cases, brightness and textural changes due to melt processes on the ice may be successfully distinguished from variations in ice concentration. This distinction was most difficult where U.S. Navy/NOAA ice charts (Godin 1981) depict ice concentrations of less than $75 \%$; less than $10 \%$ of the basin during most of the melt season (Figure 3).

Basin-wide maps of surface brightness and texture were constructed manually in three-day increments from May through August 1977, 1979, 1984, and 1985. Repetitive coverage and characteristic textures permitted the differentiation of moving clouds from the surface (Robinson and others 1985). Interactive image processor analyses of selected scenes showed good agreement with visual classification of surface brightness. Maps were digitized using the National Meteorological Center standard grid which divides the basin into 212 cells. At least one cloud-free scene per 3-day interval was available over more than $80 \%$ of the basin from May to mid-August. Missing cells were either: (1) assigned observed brightness values from an immediately preceding or subsequent chart, (2) considered to be open water, if shown as such on the Navy/NOAA weekly ice chart closest to the analyzed interval, or (3) handled as missing data (less than $10 \%$, on average).

Four ice-surface classes are identified. The literature on ground and aerial observations, referred to earlier, shows that these classes represent: class (1) fresh snow cover over $95 \%$ of the ice; class (2) snow covers between $50-95 \%$ of the surface, with the remainder being bare or ponded ice (in spring this is considered the initial stage of active snow melt); class (3) the final stage of active snow melt, with between $10-50 \%$ of the ice surface snow covered and with numerous melt ponds, or, following pond drainage, predominantly bare ice, with snow patches and scattered ponds; and class (4) heavily ponded or flooded ice with less than about $10 \%$ snow cover, or exposed bare ice.

Local observations indicate that when class 3 is iirst identified the surface is in the final stage of active melt and remains so for approximately the next $2-3$ weeks. At later dates, when class 3 is charted, the surface is predominantly drained bare ice (Kuznetsov and Timerev 1973; Hanson 1980). Classes 2 and 3 are illustrated for the Beaufort Sea in Figure 2. Class 4 is most commonly found in regions of fast ice. The absence of the numerous flaws and leads in the fast ice and its proximity to surface runoff from land results in more extensive flooding of this ice than over pack ice.

Large-scale surface albedo values adopted for the charted classes are: class (1) 0.80 ; class (2) 0.64 ; class (3) 0.49 ; and class (4) 0.29 , with standard deviations between 0.08 (class 3 ) and 0.05 (class 4 ). These values were adjusted for average summer cloudiness (Robinson and others 1985) by \pm 0.05 for brightness classes $1-3$ and \pm 0.02 for class 4 , based on data from Buzuyev and others (1965), Kuznetsov and Timerev (1973) and Grenfell and Perovich (1984). Albedo is also decreased to account for the presence of open water within the pack (Cogley, 1979). For class 1 , the correction ranges from -0.17 when the ice concentration is $75 \%$, to -0.01 when the ice concentration is $99 \%$. Ice concentrations were based on U.S. Navy/NOAA weekly ice charts.

Class albedos were calculated by measuring the brightness of selected clear-sky scenes on a digital image processor. Linear interpolation was made between homogeneous bright snow on multiyear ice and dark openwater. Clear-sky albedos of these targets were estimated from measured ground and aerial data (e.g. Hanson 1961, Nazintsev 1964, Langleben 1971, Bryazgin and Koptev 1970,

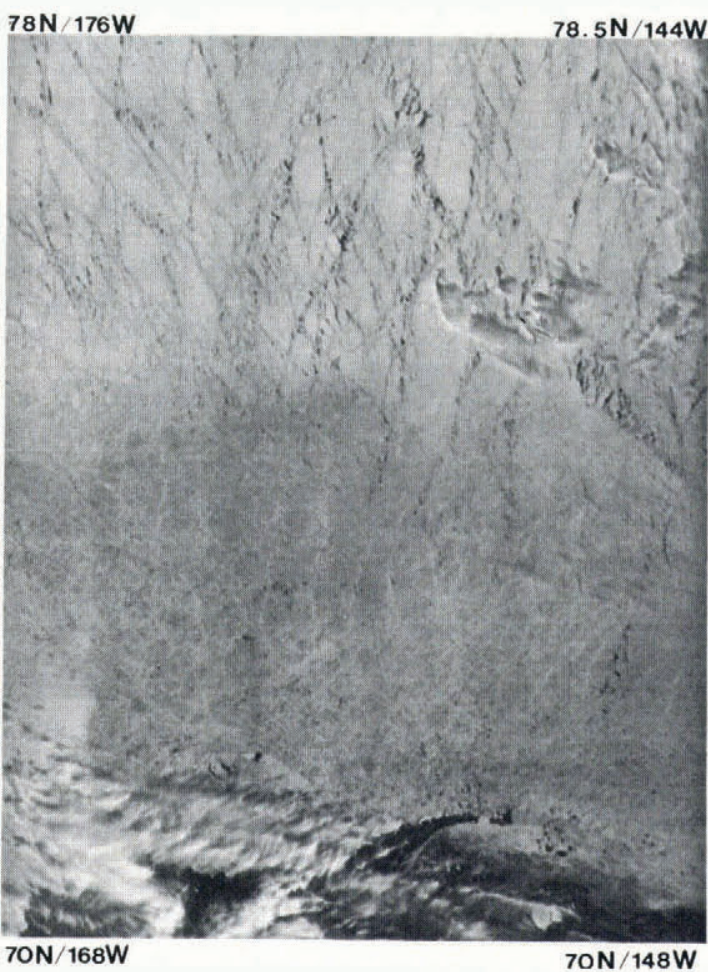

Fig.2. High-resolution $(0.6 \mathrm{~km})$ DMSP shortwave image of the Beaufort Sea on June 17, 1978 showing stages of snow melt (classes $2 \& 3$ ) on the sea ice.

Payne 1972, Grenfell and Maykut 1977, Pautzke and Hornof 1978, Cogley 1979). The snow-covered targets were assigned an albedo of 0.80 until late June, after which a value of 0.70 was used. The open-water albedo was taken as 0.12 . Specular reflectance is minimal over these surfaces at relatively high solar zenith angles during the Arctic summer and at the satellite viewing time and angle (Taylor and Stowe 1984). This procedure has been used in other studies (e.g. Preuss and Geleyn 1980; Robinson and Kukla 1985) and found to be particularly well suited for use with the broad-band DMSP imagery (Shine and Henderson-Sellers 1984).

\section{RESULTS}

Our maps show that in all four years melt began in the Barents and Kara Seas and the southern Beaufort and Chukchi Seas, then progressed along the Arctic coast of Asia and towards the American side of the Pole. In 1977, active melt (classes 2 and 3) covered $50 \%$ of the basin by the end of May (Figure 3A), while over half of the basin was categorized as class 3 or 4 by the end of June. Melt began almost 3 weeks later in 1979 (Figure 3B), yet, as in 1977 , more than half of the basin was classified as class 3 or 4 by the end of June. In 1984, melt began prior to May 1 in the southern Beaufort and Chukchi Seas (Figure 3C). However, it was not as extensive in May as it was in 1977. In 1984, areas with concentrated narrow leads in seas bordering the Asian continent resulted in a large-scale surface brightness equivalent to unbroken ice undergoing partial melt (class 2). This gives the appearance in Figure 3C of quite extensive basin snow melt early in May. However, an examination of high-resolution DMSP and AVHRR images indicates that while melt did begin quite early in the southern Beaufort and Chukchi Seas and portions of the Kara and Barents Seas in 1984, it did not begin over more than $10-15 \%$ of the basin until late May. Over half of the basin was classified as classes 3 and 4 by the end of June 1984. Melt began at about the same time in 1985 (Figure 3D) as in 1979, with about 25\% of the basin categorized as class 2 at the end of May. Approximately $50 \%$ of the basin was classified as classes 3 and 4 by the end of June. 

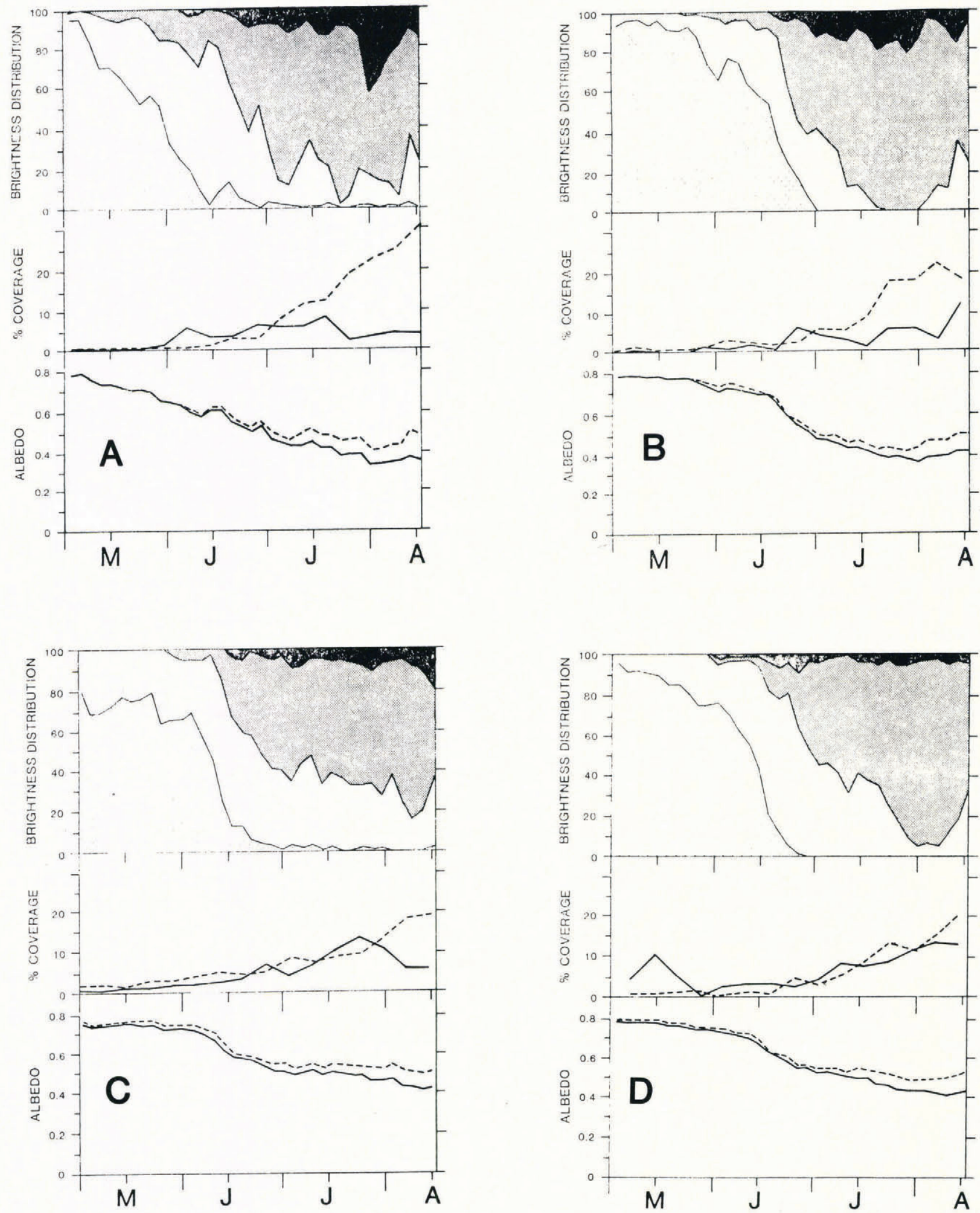

Fig.3. A. top: Progression of snow melt and subsequent ponding and drainage on Arctic sea ice from May to mid-August 1977, as shown by the changing distribution of brightness classes (cf. text for class descriptions). Classes shaded from light grey (class 1) to dark grey (class 4). Areas with less than $12 \%$ ice concentration or open water omitted.

middle: Percentage of the basin with open water or with less than a $12 \%(1 / 8)$ concentration of ice (dashed line) and percentage of the basin with a $12 \%-75 \%(1-6 / 8)$ ice concentration (solid), according to 1977 weekly Navy/NOAA ice charts. bottom: Basin-wide albedo (including sea ice and open water) from May-August 1977 (solid line). Albedo of ice (sea water excluded) in areas with at least $75 \%$ ice concentration (dashed).

B. Same as $3 \mathrm{~A}$, except for 1979.

C. Same as 3A, except for 1984 and ice concentrations of $10 \%(1 / 10)$ and $80 \%(8 / 10)$ where marked as $12 \%$ and $65 \%$ in $\mathrm{A}$.

D. Same as $3 \mathrm{~A}$, except for 1985 and ice concentration of $10 \%$ and $80 \%$. 
All sectors of the basin showed signs of melt by the beginning of July, although there were considerable year-toyear variations in melt intensity during this month. In 1977, a mid-month snowfall in the central Arctic temporarily brightened the surface and increased the albedo. Melt advanced steadily in July 1979, leaving the area essentially snowfree by the last week of the month. The central Arctic continued to have a considerable snow cover throughout July 1984, as was the case until the last week of the month in 1985 .

Soon after the minimum albedo was reached in late July or early August of each year, fresh snow began once again to cover the central part of the basin. The newly snow-covered areas did not appear as bright on the imagery as full spring cover, probably due to the presence of open leads and undrained ponds. Out of the four years, snow cover was most extensive by mid-August 1985. Heavy cloudiness allowed only sporadic views of the basin surface in the latter half of all Augusts, when it appeared that fresh snow increasingly covered the basin.

Due to the earlier melt in 1977 and the combination of melt and lower ice concentration in 1984, basin albedo averaged 0.73 in May 1977 and 1984, compared with 0.77 in 1979 and 0.76 in 1985 (Table I) Basin albedo was highest in June $1979(0.66)$, and lowest in June $1977(0.58)$

TABLE I. AVERAGE SURFACE ALBEDO OVER THE ARCTIC BASIN (FOR EACH MONTH IN THE FOUR STUDY YEARS)

$\begin{array}{lllll} & \underline{1977} & \underline{1979} & \underline{1984} & \underline{1985} \\ \text { May } & 0.73 & 0.77 & 0.73 & 0.76 \\ \text { June } & 0.58 & 0.66 & 0.61 & 0.65 \\ \text { July } & 0.43 & 0.44 & 0.48 & 0.48 \\ \text { August* } & 0.36 & 0.40 & 0.42 & 0.42\end{array}$

* for the period August 1-17

By July, basin albedo dropped to 0.43 in 1977, 0.44 in 1979, and 0.48 in 1984 and 1985. The first half of August averaged 0.36 in 1977, and between 0.40 and 0.42 in the other years, the major difference in 1977 being the relatively large amount of open water in the basin (Figure
3). The late July and early August albedo of the ice surface (sea water excluded) in those parts of the basin where ice concentration exceeded $75 \%$ was approximately 0.45 in 1977 and 1979 and 0.50 in 1984 and 1985 (Figure $3)$.

A regional breakdown (Figure 1) of surface albedo shows that the early advance of extensive snow melt in 1977 compared with the other three years was most pronounced in the Central Arctic (Table II). Later in the summer the albedo differences between years in the coastal seas were a result of differences in ice extent. This is particularly evident in the East Siberian and Laptev Seas, where the early August albedo ranged between 0.25 (1977) and 0.47 (1984)

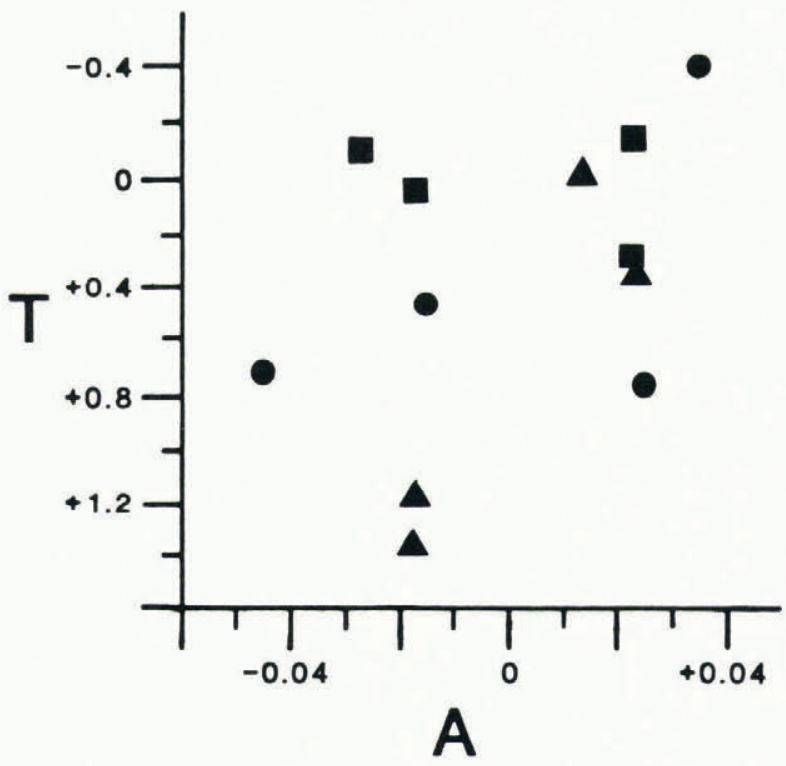

Fig.4. Comparison of monthly anomalies of surface albedo over the Arctic Basin and surface air temperature from $65-85^{\circ} \mathrm{N}$ for May (triangles), June (circles) and July (squares) of the four study years. Albedo anomalies from the average of the four years. Temperature anomalies based on 1951-1970 means (Jones 1985; Climate Monitor $1985 \mathrm{a}, 1985 \mathrm{~b})$

TABLE II. AVERAGE SURFACE ALBEDO OVER REGIONS OF THE ARCTIC BASIN (FOR EACH MONTH IN THE FOUR STUDY YEARS)

\begin{tabular}{|c|c|c|c|c|c|c|}
\hline & & $\begin{array}{l}\text { Central } \\
\text { Arctic } \\
\end{array}$ & $\begin{array}{l}\text { Beaufort/ } \\
\text { Chukchi }\end{array}$ & $\begin{array}{l}\text { E. Siberian/ } \\
\text { Laptev }\end{array}$ & $\begin{array}{c}\text { Kara/ } \\
\text { Barents }\end{array}$ & $\begin{array}{l}\text { NW North } \\
\text { Atlantic } \\
\end{array}$ \\
\hline May & $\begin{array}{l}1977 \\
1979 \\
1984 \\
1985\end{array}$ & $\begin{array}{l}0.78 \\
0.79 \\
0.79 \\
0.79\end{array}$ & $\begin{array}{l}0.74 \\
0.76 \\
0.75 \\
0.77\end{array}$ & $\begin{array}{l}0.73 \\
0.79 \\
0.74 \\
0.79\end{array}$ & $\begin{array}{l}0.66 \\
0.77 \\
0.63 \\
0.69\end{array}$ & $\begin{array}{l}0.72 \\
0.73 \\
0.70 \\
0.74\end{array}$ \\
\hline June & $\begin{array}{l}1977 \\
1979 \\
1984 \\
1985\end{array}$ & $\begin{array}{l}0.66 \\
0.76 \\
0.69 \\
0.73\end{array}$ & $\begin{array}{l}0.58 \\
0.62 \\
0.59 \\
0.65\end{array}$ & $\begin{array}{l}0.55 \\
0.67 \\
0.63 \\
0.62\end{array}$ & $\begin{array}{l}0.48 \\
0.58 \\
0.51 \\
0.54\end{array}$ & $\begin{array}{l}0.60 \\
0.62 \\
0.59 \\
0.62\end{array}$ \\
\hline July & $\begin{array}{l}1977 \\
1979 \\
1984 \\
1985\end{array}$ & $\begin{array}{l}0.52 \\
0.53 \\
0.58 \\
0.59\end{array}$ & $\begin{array}{l}0.42 \\
0.41 \\
0.45 \\
0.47\end{array}$ & $\begin{array}{l}0.40 \\
0.42 \\
0.49 \\
0.48\end{array}$ & $\begin{array}{l}0.27 \\
0.32 \\
0.30 \\
0.31\end{array}$ & $\begin{array}{l}0.46 \\
0.45 \\
0.50 \\
0.47\end{array}$ \\
\hline August* & $\begin{array}{l}1977 \\
1979 \\
1984 \\
1985\end{array}$ & $\begin{array}{l}0.50 \\
0.53 \\
0.54 \\
0.54\end{array}$ & $\begin{array}{l}0.33 \\
0.37 \\
0.42 \\
0.41\end{array}$ & $\begin{array}{l}0.25 \\
0.39 \\
0.47 \\
0.45\end{array}$ & $\begin{array}{l}0.19 \\
0.22 \\
0.15 \\
0.17\end{array}$ & $\begin{array}{l}0.44 \\
0.43 \\
0.43 \\
0.44\end{array}$ \\
\hline
\end{tabular}

* for the period August 1-17 
In the central Arctic, where ice concentration generally remains above $95 \%$ throughout the summer, the July albedo was 0.52 in $1977,0.53$ in $1979,0.58$ in 1984 and 0.59 in 1985. These satellite-derived albedos are within the range of published estimates (e.g. Hanson 1961, Larsson and Orvig 1962; Posey and Clapp 1964; Marshunova and Chernigovskiy 1966; Schutz and Gates 1972, Hummel and Reck 1979; Robock 1980; Kukla and Robinson 1980; Barry 1983; Carsey 1985), which vary from 0.40 to 0.65 . The large range of the estimates reflects the high year-to-year variability in the extent of snow melt, degree of ponding and frequency of summer snowfalls. Differing approaches and limited data bases available to earlier researchers may also be a factor.

Towards the middle of August, when the extent of fresh snow cover in the central Arctic began to increase, albedo rose by 0.05 to 0.10 in all years; however, our satellite-derived albedo in the first half of August is lower than that reported earlier from drifting stations (Nazintsev 1964, Pautzke and Hornof 1978). This may be the result of our large-scale averaging, as opposed to the ground observations made mostly on thick multi-year ice surrounding drifting stations. Alternatively, the August snowfalls may have come relatively late or been less extensive in the four years of our study.

\section{DISCUSSION}

The geographic progression of seasonal melt identified in our maps was compared with earlier studies. The climatological summary of Marshunova and Chernigovskiy (1978) shows a concentric pattern of melt over the Arctic pack ice progressing towards the Pole by early July. From a study of sequential ESMR data for 1974, Campbell and others (1980) suggested that melt began along the Siberian coast in May and moved as a roughly linear front across the Pole, reaching the Canadian and Greenland coasts about a month later. Re-examination of their data by Crane and others (1982), indicated that the color coding of the microwave imagery created a partially spurious impression of a progressing melt front.

Climate models suggest that an early loss of snow cover may have an impact on ice extent later in the summer (Maykut and Untersteiner 1971; Semtner 1976). In 1977. when the snow melt and ponding came early, the subsequent late summer ice extent was considerably reduced compared to ice cover in the other years. This relationship was most evident in the Beaufort and Chukchi Seas and the East Siberian and Laptev Seas regions. Whether such a dependence was coincidental or not must remain speculative until more years are examined.

Cloud cover, mapped at approximately three-day intervals in the summers of 1977 and 1979, showed a late May-early June maximum in extent (averaging approximately $90 \%$ ) and thickness over the basin, followed by a period of less extensive (approximately 75\%) and somewhat thinner cover extending into early August (Robinson and others 1985). This suggests that early stages of surface melt may be related to the early season cloudiness, which appears to be associated with the poleward retreat of the Arctic front and advection of air from lower latitudes by synoptic disturbances (Barry and others 1986). Early melt may also be enhanced by the increase in infrared radiation at the surface due to the cloud cover. This results in an increase in surface net radiation over high-albedo Arctic surfaces (e.g. Ambach 1974).

The relationship between snow melt onset and largescale Arctic surface air temperatures was examined using monthly temperature and albedo anomalies (Figure 4). Temperature anomalies are based on 1951-1970 means for $65-85^{\circ} \mathrm{N}$ (Jones 1985; Climate Monitor 1985[a] and $1985[\mathrm{~b}])$. Albedo anomalies are calculated from the average of the four study years (cf. Table I). A relationship between positive anomalies of temperature and negative anomalies of basin-wide surface albedo is apparent in May and three of the Junes studied, but is not evident in July. This suggests that the temperature data are not representative of the inner Arctic Basin, but are related to melt in the coastal seas located near the reporting stations.

\section{CONCLUSION}

This work provides the first direct evidence of the fluctuations of snow cover and surface albedo across the entire Arctic Ocean in spring and summer. The timing of snow melt on the Arctic sea ice is shown to vary greatly from region to region as well as from year to year. This variation will have a significant impact on the heat and mass balance of the Arctic, since the surface albedo and the thermodynamics of the ice are strongly related to the presence of snow. Improved knowledge of the spring and summer surface albedo in the Arctic is important in climate models and may also help in recognizing the initial signs of any climatic changes induced by $\mathrm{CO}_{2}$ and other trace gases.

\section{ACKNOWLEDGEMENTS}

We thank D. van Metre and S. Innes for assistance in the analysis. DMSP data are archived for NOAA/NESDIS at the University of Colorado, CIRES/National Snow and Ice Data Center, Campus Box 449, Boulder, CO 80309. This work was supported by NSF grant ATM 83-18676 and the Air Force Office of Scientific Research, Air Force Systems Command, USAF, under grant AFOSR 86-0053. The U.S. Government is authorized to reproduce and distribute reprints for Governmental purposes notwithstanding any copyright notation thereon. This is LDGO contribution 4026.

\section{REFERENCES}

Ambach W 1974 The influence of cloudiness on the net radiation balance of a snow surface with high albedo. Journal of Glaciology 13(67): 73-84

Barry R G 1983 Arctic Ocean ice and climate: perspective on a century of polar research. Annals of the Association of American Geographers 73: 485-501

Barry R G 1985 The cryosphere and climate change. In MacCracken M, Luther F (eds) Detecting the climatic effects of increasing carbon dioxide. Washington, DC, United States Department of Energy: 109-148 (DOE/ER-0235)

Barry R G, Crane R G, Newell J P, Schweiger A 1986 Empirical and modeled synoptic cloud climatology of the Arctic Ocean. Boulder, CO, University of Colorado. Cooperative Institute for Research in Environmental Sciences

Bryazgin N N, Koptev A P 1970 Spectral albedo of snow-ice cover. Problems of the Arctic and the Antarctic 31: $355-360$

Buzuyev A Ya, Shesterikov N P, Timerev A A 1965 Al'bedo l'da $\mathrm{v}$ arkticheskikh moryakh po dannym nablyudeniy s samoleta [Albedo of ice in Arctic seas from air observation data]. Problemy Arktiki $i$ Antarktiki 20: 49-54

Campbell W J, Ramseier R O, Zwally H J, Gloersen P 1980 Arctic sea-ice variations from time-lapse passive microwave imagery. Boundary-Layer Meteorology 18(1): 99-106

Carsey F D 1985 Summer Arctic sea ice character from satellite microwave data. Journal of Geophysical Research 90(C3): 5015-5034

Climate Monitor 1985[a] Update table for graphs. Climate Monitor 14: 42

Climate Monitor 1985[b] Update table for graphs. Climate Monitor 14: 82

Cogley J G 1979 The albedo of water as a function of latitude. Monthly Weather Review 107: 775-781

Crane R G, Barry R G, Zwally H J 1982 Analysis of atmosphere-sea ice interaction in the Arctic Basin using ESMR microwave data. International Journal of Remote Sensing 3: $259-276$

Fletcher J O 1966 The Arctic heat budget and atmospheric circulation. In Fletcher $\mathrm{J} O(e d)$ Proceedings of the Symposium on the Arctic Heat Budget and Atmospheric Circulation... 1966, Lake Arrowhead, California. Sant Monica, CA, Rand Corporation: 23-43

Godin R H 1981 Sea ice charts of the Navy/NOAA Joint Ice Center. Glaciological Data Report GD-11: 71-77

Grenfell T C, Maykut G A 1977 The optical properties of ice and snow in the Arctic Basin. Journal of Glaciology 18(80): $445-463$ 
Grenfell T C, Perovich D K 1984 Spectral albedos of sea ice and incident solar irradiance in the southern Beaufort Sea. Journal of Geophysical Research 89(C3): 3573-3580

Hanson A M 1980 The snow cover of sea ice during the Arctic Ice Dynamics Joint Experiment, 1975 to 1976. Arctic and Alpine Research 12(2): 215-226

Hanson K J 1961 The albedo of sea-ice and ice islands in the Arctic Ocean basin. Arctic 14(3): 188-196

Holt B, Digby S A 1985 Processes and imagery of first-year fast sea ice during the melt season. Journal of Geophysical Research 90(C3): 5045-5062

Hummel J R, Reck R A 1979 A global surface albedo model. Journal of Applied Meteorology 18: 239-253

Jones P D 1985 Arctic temperatures 1951-1984. Climate Monitor 14: 43-49

Kukla G, Robinson D 1980 Annual cycle of surface albedo. Monthly Weather Review 108(1): 56-68

Kuznetsov I M, Timerev A A 1973 The dependence of ice albedo changes on the ice cover state as determined by airborne observations. Problems of the Arctic and the Antarctic 40: 67-74

Laktionov A F (ed) 1953 Rukovodstvo dlya nablyudeniyy nad l'dami arkticheskikh morey, rek $i$ ozer na polyarnykh gidrometeorologicheskikh stantsiyakh [Handbook for observing the ice of Arctic seas, rivers and lakes at polar hydrometeorological stations]. Leningrad, Izdatel'stvo Glavsevmorputi (Posobiya i Rukovodstva 31)

Langleben M P 1971 Albedo of melting sea ice in the southern Beaufort Sea. Journal of Glaciology 10(58): 101-104

Lapp D 1982 A study of ice meltponds. Toronto, Atmospheric Environment Service

Larsson P, Orvig S 1962 Albedo of Arctic surfaces. Montreal, McGill University (Publications in Meteorology 54)

Marshunova M S, Chernigovskiy N T 1966 Numerical characteristics of the radiation regime in the Soviet Arctic. In Fletcher J O (ed) Proceedings of the Symposium on the Arctic Heat Budget and Atmospheric Circulation. 1966, Lake Arrowhead, California. Santa Monica, CA, Rand Corporation: 279-297

Marshunova M S, Chernigovskiy N T 1978 Radiation regime of the foreign Arctic. New Delhi, Indian Scientific Documentation Centre for the Office of Polar Programmes; Washington, DC, National Science Foundation (Technical Translation 72-51034)

Maykut G A, Untersteiner N 1971 Some results from a time-dependent, thermodynamic model of sea ice. Journal of Geophysical Research 76(6): 1550-1575

Nazintsev Yu L 1964 Teplovoy balans poverkhnosti mnogoletnego ledyanogo pokrova $\mathrm{v}$ Tsentral'noy Arktike [Surface heat balance of the perennial ice sheet of the central Arctic]. Trudy Arkticheskogo $i$ Antarkticheskogo Nauchno-Issledovatel'skogo Instituta 267: 110-126

Pautzke C G, Hornof G F 1978 Radiation regime during AIDJEX: a data report. AIDJEX Bulletin 39: 165-185

Payne R E 1972 Albedo of the sea surface. Journal of the Atmospheric Sciences 29: 959-970

Posey J W, Clapp P F 1964 Global distribution of normal surface albedo. Geofisica Internacional 4: $33-48$

Preuss H J, Geleyn J F 1980 Surface albedos derived from satellite data and their impact on forecast models. Archives for Meteorology, Geophysics and Bioclimatology Ser A 29: $345-356$

Robinson D A, Kukla G 1985 Maximum surface albedo of seasonally snow-covered lands in the northern hemisphere. Journal of Climate and Applied Meteorology 24: 402-411

Robinson D A, Kukla G J, Serreze M C 1985 Arctic cloud cover during the summers of 1977-1979. Palisades, NY, Lamont-Doherty Geological Observatory (Technical Report L-DGO-85-5)

Robock A 1980 The seasonal cycle of snow cover, sea ice and surface albedo. Monthly Weather Review 108(3): 267-285

Schutz C, Gates W L 1972 Global climatic data for surface, $800 \mathrm{mb}, 400 \mathrm{mb}$ : July. Santa Monica, CA, Rand Corporation

Semtner A J Jr 1976 A model for the thermodynamic growth of sea ice in numerical investigations of climate. Journal of Physical Oceanography 6(3): 379-389
Shine K P, Henderson-Sellers A 1984 Cryosphere-cloud interactions near the snow/ice limit: sensitivity testing of model parameterizations. In Barry $\mathrm{R} G$, Shine $\mathrm{K} P$, Henderson-Sellers A Cryosphere-cloud interactions near the snow/ice limit. Boulder, $\mathrm{CO}$, University of Colorado. Cooperative Institute for Research in Environmental Sciences; Liverpool, University of Liverpool. Department of Geography: 77-236

Taylor V R, Stowe L L 1984 Reflectance characteristics of uniform earth and cloud surfaces derived from NIMBUS-7 ERB. Journal of Geophysical Research 89(D4): $4987-4996$

Untersteiner N 1961 On the mass and heat budget of Arctic sea ice. Archives for Meteorology, Geophysics and Bioclimatology Ser A 12: 151-182

Weaver R L, Barry R G, Jacobs J D 1976 Fast ice studies in western Davis Strait. In POAC 75: the Third International Conference on Port and Ocean Engineering under Arctic Conditions, Fairbanks, Alaska, 1975. Proceedings Vol 1: 455-466

Zubov N N 1945 L'dy Arktiki [Arctic ice]. Moscow, Izdatel'stvo Glavsevmorputi [English translation: Washington, DC, US Navy Oceanographic Office] 